\title{
1950 and the Crisis of the American Interior
}

\author{
Charles Lemert
}

\begin{abstract}
Nobody dast blame this man. You don't understand: Willy was a salesman. And for a salesman, there is no rock bottom to the life. He don't put a bolt to a nut, he don't tell you the law or give you medicine. He's a man way out there in the blue, riding on a smile and a Shoeshine. And when they start not smiling back-that's an earthquake. And then you get yourself a couple of spots on your hat, and you're finished. Nobody dast blame this man. A salesman is got to dream, boy. It comes with the territory.

— Requiem for Willy Loman, Death of a Salesman
\end{abstract}

Arthur Miller's Death of a Salesman opened on Broadway February 10, 1949. Tennessee Williams' Streetcar Named Desire opened on Broadway just more than a year before on December 3, 1947. Both were tragedies of American consciousness. In Miller's play Willy Loman killed himself at least as much because he has lost himself as for the shame of being found out by Biff, his son, in the midst of a fatal affair. In Williams' Streetcar, Blanche, lost in the chaos of her life, is committed to a mental hospital where out of her confusion she utters the famous line: "Whoever you are, I have always depended upon the kindness of strangers." Then too, earlier (in 1942), Eugene O'Neill finished writing Long Day's Journey into Night, a play that like the other day dramatizes a family's descent into ruin.

Each play in its way foretells the crisis of the day and of the times. This is why they are widely considered the three most important theatrical dramas of America's 20 th century. It is a truism of sorts that art is the early warning system of a culture's coming crisis.

But what, exactly, was that crisis? O’Neill's Long Day's Journey into Night was written in wartime. Yet, in America, the shock of Pearl Harbor late in 1941, was but a prompt to a period of mobilization and global triumph in 1945. Also, in 1941, before Pearl Harbor, Henry Luce coined the celebratory assertion that the 20th was the American Century. Long Day's Journey into Night, that same year, was a probe below a national innocence that still now holds some in its spell. It is, thus, properly of the same conjuncture as Death of a Salesman and Streetcar Named Desire. In their time, hot war in the past, the Cold War was already chilling America's brief moment of shear global dominance from August, 1945 to Winston Churchill's Iron Curtain speech at Westminster College in Fulton, Missouri, on March 5, 1946. Yet, at home, many Americans were living the good life later analyzed in John Kenneth Galbraith's 1957 book, The Affluent Society. Post-war affluence was widely thought to be a new day for the working class. That there was another, darker class of poor and racially excluded Americans was not at all on the radar of the liberal intelligentsia. (Michael Harrington's The Other America would not be published until 1962 when it got John F. Kennedy's attention.)

In 1941 America remained, for most part, blissfully innocent of what would come in 1950. The 1940s playwrights were not. The year after Death of a Salesman, however, all but the most naive could not help but think that something had begun to fade from an original belief in an America's special providence built on hard work. On February 9, 1950, Senator Joseph McCarthy gave his notorious Red Scare speech in Wheeling, West Virginia claiming that he had a list of Communists working for the State Department. The speech was not recorded. He waved a list allegedly naming anywhere from 57 to 284 sympathizers. No one saw the list. Then began an internal crisis of American consciousness. McCarthyism quickly came to represent the extent to which one could not trust 
even the most trustworthy public servants - teachers, diplomats, politicians, actors, army officers, and, in effect (and in principle) anyone who did not tow an imperceptible ideological line.

The crisis quickly found ample global evidence for fear. On February 14, 1950, just five days after McCarthy's Wheeling speech, the Soviet Union and the People's Republic of China signed a mutual defense pact -- an accord by the world's two largest communist nations made all the more threatening by the fact that, the year before, Mao's Communist Party had defeated Chiang Kai-shek's Nationalist Party. Then on September 6, 1950, President Harry S. Truman ordered American troops to defend South Korea against the North. The initial results were disastrous. North Korea over ran most of the South until General Douglas MacArthur's brilliant naval end run from Pusan in the very south to retake Inchon in the north. Soon after on October 19, 1950, the world was again at world when China entered the Korean Peninsula. Then and there Global Communism was aligned against United Nation troops representing something like Global Democracy.

McCarthy was censured by the United States Senate on December 2, 1954. The hot war in Korea ended in an armistice on July 27, 1953. Yet, as is perfectly evident, variants of Senator McCarthy's baseless scare tactics linger on today, however attenuated, in the delusional racist attacks on President Barack Obama. So too Korea, remains divided under ever more insane token Communist leaders. Technically the 1950-1953 war is still on, thus lending Vin Diesel and Dennis Rodman a certain entertainment value. The global threat of North Korea remains serious.

Though replayed against different circumstances, the crises of 1950 endure. It was then, as the three great plays of the 1940s foretold, that American culture began to doubt itself. To be sure, listening to political speeches today, that doubt is very well repressed. Yet, few on the intelligent Left can deny that America, at least, soon perhaps Europe as well, eventually the so-called West are in decline. Among social scientists, none put the fact of American decline sooner and more pungently than Immanuel Wallerstein in "American and the World" in February, 1992, in Theory and Society. It was here that Wallerstein declared that the then present was a period from, precisely, 1945 and 1989-91 — a period in which American exceptionalism fed a cultural founded on hybrids and Calvinist guilt. Put somewhat too psychoanalytically, pride is an external expression of the ravages of internal guilt-and expression that takes the form of violence when attempts to love away the guilt fail, as always they do.

It is not often that social scientists are as prescient as artists can be- a sad fact illustrated by the 19th century founders of the social sciences who were, at least, a good generation behind in diagnosing the crises of their times. Emile Durkheim's anomie lagged well behind Alfred Jarry and the absurdists (and never quite got the point even after the Cubist movement in Paris between 1906 and 1911). Max Weber's dread of the iron cage may have been a remote consequence of his appreciation of Nietzsche but Weber's inability to see beyond over-rationalization lacked all the poetic intensity of Nietzsche's aphoristic genius in, say, the uncompromising disdain for European culture in Twilight of the Idols (1888).

Not even Sigmund Freud - whose 1990 Interpretation of Dreams was, in its way, more deeply radical than the key ideas of other of the classic social theorists-had to reinvent himself two decades later in Beyond the Pleasure Principle (1920) wherein his dual drive theory exposed the probability that the Unconscious is as much about deadly violence as about creative love. Hence, another decade later, in Civilization and Its Discontents (1930), he would articulate the lesson of the violence of the Great War and of the greater war already in the making early in the 1930s. Freud, ever the scientist, was not the poet Karl Marx was, but it is well known that he read widely in the literature of his day and that his consulting office was decorated in ancient art from Africa. This aside, for any thinker in his declining years (Freud was seventy-four in 1930) to make so great an intellectual leap as he did to a theory of the primordial evil in modern civilization one must be a poet of sorts; and especially so when the social theory of his declining years was so apt to the times and so at odds with prevailing sentiment.

Marx, however, was markedly the finest poet of the lot. "All that is solid melts into air all that is holy is profaned, and man is at last compelled to face with sober sense, his real conditions of life, and his relations with his kind." Here, in the most imaginative line of the 1845 Manifesto, Marx (with Engels' consent, one supposes) puts forth the utopian resolution of the contradictions in his highly abstract theory of alienation of the year before in the 1844 Economic and Philosophical Manuscripts. Even Freud and Marx, the most poetic of the early social thinkers, could do no more than paint a picture of global violence, in the one case, and of the hope of a social revolution, in the other. In this respect, one is hard-pressed to say than any of the founders of modern social thought came any more than close to a robust theory of just how deep the crises of their industrializing generations were. Though each was a prophet of a sort, none even began to outline an enduring theory of how, if at all, science might contribute to the deep structural contradictions of the modern world. Nor did any of their contemporaries. William James and Georg Simmel (if not Herbert Spencer) were influential thinkers with their own poetic flair, but neither did better than the 
canonical fathers of the social sciences.

The forgivable failures of the fathers stand in sharp contrast to a short list of remarkably innovative thinkers who published major and enduring works in and close after 1950. By contrast to those who preceded them (and, sadly, most who have come after) all of them wrote enduringly influential master works that came hard on the heels of the great American tragedies of the 1940s. All dealt directly or indirectly with the crisis of 1950 — that of the cancerous collapse of the American self-confidence in the integrity of the interior lives of both the individual and the nation. The four notables were David Riesman, Erik Erikson, Erving Goffman, and Edwin Lemert. All wrote clearly. None (with the possible exception of Goffman) possessed any particular artistic or literary flair. As individuals, none was quite like any of the others.

At the time, only Lemert and Goffman were certifiable sociologists (though, as time would tell, Goffman always defied the terms and conditions of normal social science). Riesman was a lawyer teaching social studies at the University of Chicago. Erikson, of course, was and would remain a psychoanalyst. Each wrote texts in or close by1950; namely: Riesman's Lonely Crowd, Erikson's Childhood and Society, Goffman's “Cooling the Mark Out," and Lemert's Social Pathology. Each text was formative in two senses: as key to the author's intellectual career; as a path breaking work that changed social and analytic thought for years to come. Yet, the authors were different one from the others; and each was idiosyncratic in his own way. Nevertheless, though each wrote an accessible, even elegant, style that made his work important beyond their immediate fields of endeavor, none was a popularizer. What did they, collectively achieve, in relation to the crisis foretold by the playwrights? How did they engage the crisis and redefine it for those who came after?

David Riesman's Lonely Crowd: A Study of the Changing American Character was written with Nathan Glazer and Reuel Denney. More than any other book of the day, Lonely Crowd diagnosed the crises in the American national character by finishing the story first told by Max Weber. Where Weber famously defined and described the transformation of Western culture from the eternal yesterday of traditionalism to the desperately rule-bound culture of the individualistic entrepreneur, Riesman wrote of the collapse of that very individualism based as it was on an interior sense of self-directed, productive work in the world. Both Weber and Riesman were, in their ways, fatalistic about the horrors of the iron cage and moral consequences of other-directed conformism. Weber's rational individual was trapped. Riesman's inner-directedness was fading away in a culture of adjustment and conformity to the expectations and faddish norms of others_-of, that is, ultimately of the demands of an American national character that was losing its traditional ways. For example, from the introductory chapter of Lonely Crowd: A Study of the Changing American Character:

What is common to all other-directed people is that their contemporaries are the source of direction for the individualeither those known to him or those with whom he is individually connected, through friends and through the mass-media. This source is of course "internalized" in the sense that dependence on it for guidance in life is implanted early. The goals toward which the other-directed person strives shift that guidance: it is only the process of striving itself and the process of paying close attention to the signals from others that remain unaltered throughout life.

Pretty good sociology for a young lawyer without training in the field.

And good enough to become a best seller for years to come. Lonely Crowd has sold more than1.5 million copies over the years, more than any other sociology book in the modern era. The book is a sprawling interpretative and theoretical discussion the American character and its perturbations in the post-WWII era. Though readable enough to be widely read, Lonely Crowd is a technically subtle scholarly work and scholarly enough for Riesman, in subsequent editions, to criticize what he came to consider his over-reaches and other mistakes. Yet, the book struck the very same chord Arthur Miller had struck the year before in Death of a Salesman. Like Willy Loman, Riesman other-directed man is "way out there in the blue, riding on a smile and a Shoeshine".

Erik Erikson's Childhood and Society was his first great book that was written for psychoanalysts. It nodded here and there to what he would name in so many words in his 1968 book Identity: Youth and Crisis. Technical though it was, Childhood and Society quickly won a readership that, in time, spread from those in the psychoanalytic know, to many a reader in other fields as in time it did to the general reader. There began, for example, samples of the full-blown biographical studies — Young Man Luther (1958) and Gandhi's Truth (1969)—that advanced Erikson's sophisticated approach to the link binding history to psychology. He was the founder, therefore, of psychohistory but also, more than anyone else this side of Freud, the one who understood that psychoanalytic thought and practice were embedded in histories that go well beyond the personal histories reported in session. Yet, quite in contrast to Lonely Crowd, Childhood and Society, upon first look, bore no resemblance to a book that would have the enduring 
and popular effect it has had.

Childhood and Society is still the classic text on what Erikson importantly called the "Eight Stages of Man," wherein the gender insensitive "Man" may be forgiven for its implicit reference to the natural history of Humankindhistory with roots in anthropology. The stages in Childhood and Society were, to be sure, those of the moral and social development of the child that made possible the subsequent stages of adult life. Each stage, including those of adult life, Erikson described as a tension between opposing states of emotional and mental self-understanding; thus, a crucial secondary theme, is the omnipresence of anxiety which he defines as "a diffuse state of tension."

The stage that became paradigmatic for his concept of identity crisis was adolescence for which the anxiety produced polarities are precisely identity versus role confusion. Thus in the chapter on youth in Childhood and Society (page 235):

The growing and developing youths, faced with [puberty's...] physiological revolution within them, and with tangible adult tasks ahead of them, are now primarily concerned with adult tasks ahead of them, and are now primarily concerned with what they appear to be in the eyes of others as compared with what they feel they are, and with the question of how to connect the roles and skills cultivated with the occupational prototypes of the day.

The adolescent mind is, according to Erikson, a mind in "moratorium" — frozen so to speak by the power of this particular tension in which the wish to be an autonomous individual struggles with a need to conform.

Unlike Riesman, Erikson makes no full blown commentary on American national character. But he does hint at the obvious allusion to, in effect, America's then emergent state of adolescence arising on the sudden growth of its global power and the new information technologies that aggravate awareness of fads and trends that called, the young, especially, to conformity. Some have said that "youth" was more or less invented in the day or, at the least, youth culture then came to be the provocative aspect of the affluent culture. Erikson does not go that far, but he does comment in the shallowness of American post-war moral commitments (page 276):

Today when there is so much demand for homes in defensively over-defined, overly standardized, and over-restricted neighborhoods, many people enjoy their most relaxed moments at crossroads counters, in bars, in and around automotive vehicles, and in camps and cabins, playing that they are unconfined and free to stay, free to move on. No country's population travels farther and faster.

Elsewhere, in the conclusion, Erikson introduces Arthur Miller's Willy Loman's son, Biff, as a prototype of the American adolescent who, like his father, can't figure out how to live a life that dependents on nor more than a smile and a Shoeshine. Erikson never says that Biff embodied American national character at the time. But he could have.

Erving Goffman is justly famous for the locution impression management, which first appeared in his earliest book, The Presentation of Self in Everyday Life (1956). For those who might quibble that 1956, while clearly in the conjectural time of the 1950 crisis, is off date, I propose Goffman's earliest great paper, "Cooling the Mark Out"—a paper that was taking shape in 1950 when Goffman was in Scotland doing fieldwork on the Shetland Islanders, the empirical subject of Presentation of Self.

"Cooling the Mark Out: Some Aspects of Adaptation to Failure" was published upon his return in 1952. By contrast to the other works here discussed, "Cooling the Mark Out" is lesser both in length and in its foundational effects on the author and his followers. Yet, it is notable for its originality even amid the still then distinctiveness of the sociology at the University of Chicago. The Chicago School, until recently was known in sociology for contrariness amid the formal nature of the rest of American sociology. Still more so, Goffman, two years from finishing his Chicago $\mathrm{PhD}$, was defiant even in that company. Lloyd Warner, his thesis advisor, advised him to study the Shetland Island community as a whole and in a traditional ethnographic manner. Goffman chose instead to remain in his hotel to study the community interactions in that one, very local, setting. Here were planted the seeds of Goffman's central empirical frame, the interaction order, which would not be formalized until much later. For example, the opening paragraphs of "Cooling the Mark Out" (Psychiatry 15 (4): 451-52):

In the argot of the criminal world, the term "mark" refers to any individual who is a victim. ... The confidence game-the con, as its practitioners call it-is a way of obtaining money under false pretenses by the exercise of fraud and deceit.... The con is said to be a good racket in the United States because most Americans are willing, nay eager, to make some easy money, and will engage in action that is less than legal in order to do so. The typical play has typical phases. The potential sucker is first spotted, and one member of the working team (called an outside man, steerer, or roper) arranges to make the social contact with him. The confidence of the mark is won, and he is given an opportunity to invest his money in a gambling venture which he understands to have been fixed in his favor. The venture, of course, is fixed, but not in his favor. The mark 
is permitted to win some money and then persuaded to invest more. There is an "accident" or a "mistake" and the mark loses his total investment. The operators then depart in a ceremony that is called the blowoff or sting. They leave the mark but take his money.

Those already familiar with Presentation of Self will readily spot early versions of its central concepts-the con, the team, the play, the ceremonial sting. Together these dramaturgical elements explain Goffman's stunningly radical general theory as to the practice of daily life. We live with others in everyday life where, to be a self, we must manage impressions with the cooperation of a team of friends and others in the know. They support our play before others we seek to impress. When successful, our "self" is established by a con with these others in a particular setting. The con is to be recognized as the one we present ourselves to be. The mark is left with nothing tangible save the false impression that the one in whom a degree of trust was invested is, for the time being, real somehow.

Goffman develops his theory of the presented self most economically in a later book, Stigma: Notes on the Management of a Spoiled Identity (1963). Here all of the ideas outlined in "Cooling the Mark Out," "On FaceWork" (1955), and Presentation of Self come together in Goffman's discussion of the politics of identity. A social identity is one accomplished in the confidence play with others. One's personal identity comprises those knowable personal marks that if revealed in a play could destroy the con. A personal history of deviance, for example, must be covered by the control of that information in an interaction setting where one wants to be taken as a normal. The con must not allow the mark to know that the fix is on. But, finally, and in crucial reference to the crises of 1955, an ego identity is little more than the feeling the stigmatized mark has in an interaction. For example, Stigma (1963: 106):

The concept of social identity allowed us to consider stigmatization. The concept of personal identity allowed us to consider the role of information control in stigma management. The idea of ego identity allows us to consider what the stigmatized individual may feel about stigma and its management.

In other words, we are all marks with feelings about the interplay of social and personal identities. Whether a recognized deviant or a presumptive normal, all are vulnerable to being found out for what we "really" are.

It is here that Goffman cites Erik Erikson's general theory of the interplay of the personal and the social—of the adolescent need for identity while anxiously suffering the tension of the personal with the social caused by role confusion. Hence Goffman's strange idea of normal deviancy as ubiquitous among social individuals who, in effect, have no interior self they can carry from setting to setting. Curiously, it is here also that Goffman cites the fourth of the theorists of the crisis of 1950, Edwin M. Lemert.

Edwin Lemert's Social Pathology (1951) may be rightly considered the text that reinvented the theory of social deviance by introducing the idea that known deviants are created in a subtle process of societal reaction. Lemert's general theory of deviance as it appeared in Social Pathology was first outlined in a 1948 conference paper. In the book, he quotes that paper to define his theory (Social Pathology, page 22):

We must pertinently ask at this juncture whether the time has not come to break abruptly with the traditions of older social pathologists and abandon once and for all the archaic and medicinal idea that humans can be divided into normal and pathological, or, at least, if such a division must be made, to divest the term "pathological" of its moralistic unscientific overtones. ... Thus, by [...] definition, sociopathic phenomena simply become differentiated behavior which at a given time and place is socially disapproved even though the same behavior may be socially approved at other times and places.

Edwin Lemert's theory, thus announced, emerged in Social Pathology and other of his writings, as a powerful tool for examining a full range of deviant practices.

In a later article_-“The Behavior of the Systematic Check Forger” (Social Problems 6.2, 1958) —Lemert interviewed men (usually men, then) who were incarcerated for forgery. With rare exception, he found them atypical of the larger prison population. They were more highly educated. Their criminal careers required them to be creative in how they passed bad checks. They had organized their lives into a career as check-men. And, most interestingly, they were often glad to have been found out; and, once adjudicated, they were model prisoners. Why this profile? Lemert astutely interprets them as men socially isolated by having to work alone. In the day when banking was almost always done with paper checks, check-men were forced to live and move alone from place to place to avoid being found out. They were, thus, lonely and isolated for want of a favorable societal reaction to their genius. Thus, in the end, Lemert concluded, their social pathology arose upon an intolerable social condition of being alone, unappreciated by society for their unique accomplishments. Arrest and incarceration was a societal reaction that 
relieved their sense of social unworthiness. Conviction was for them a societal reaction that brought them back into the social fold.

Edwin Lemert did not become iconic among general readers as did Riesman, Erikson, and Goffman. But he clearly invented a theory of social pathology that resonated with the work of others in the crisis of 1950. Lemert's social pathology as a career composed on a string of societal reactions (or in the case of the check-men the absence thereof) depends on the more general assumption shared by the other three.

What characters we may become, for better or worse, demand a complicated social struggle for recognition by others. When the individual (or in Riesman's case, the nation) turns away from a belief in the enduring nature of the interior life (whether of a purportedly distinct self or of an exceptional national culture) then ongoing life must confront the role confusion of conformity to others.

Arthur Miller, Tennessee Williams, and Eugene O’Neill portrayed such a turn as a morbid catastrophe. David Riesman, Erik Erikson, Erik Erikson, and Edwin Lemert were not morbid. They were scientists; yet each gave vent to a kind of literary imagination that was consistent with the morbidity of the playwrights. The crisis of 1950 was a crisis wrought by a growing uneasiness with the prospects that post-war America could cash in on its new global confidence game -- whether, that is, the force of America's external obligations would rob the nation and its individuals of identities forged in a fading past of personal and national isolation. 